ECLETICA A

www.scielo.br/eq

www.ecletica.iq.unesp.br

Volume 33, número 3, 2008

\title{
Anacardic acid derivatives from brazilian propolis and their antibacterial activity
}

\author{
M. S. S. Silva', S. G. De Limal, E. H. Oliveira', J. A. D. Lopes ${ }^{1}$, M. H. Chaves ${ }^{1}$, F. A. M. Reis ${ }^{3}$, A. M. \\ G. L. Citó ${ }^{1}$ \\ ${ }^{1}$ Department of Chemistry - CCN / The Federal University of Piauí, Campus da Ininga, 64049-550 Teresina, PI, Brazil \\ ${ }^{2}$ Departament of Microbiology and Parasitology - CCS / The Federal University of Piauí \\ ${ }^{3}$ Institute de Chemistry-The State University of Campinas - UNICAMP. CP-6154; 13083-970 Campinas - SP, Brasil \\ *gracito@ufpi.br
}

\begin{abstract}
Propolis is a sticky, gummy, resinous substance collected by honeybees (Apis mellifera L.) from various plant sources, which has excellent medicinal properties. This paper describes the isolation and identification of triterpenoids and anacardic acid derivatives from Brazilian propolis and their antibacterial activity. Their structures were elucidated by ${ }^{1} \mathrm{H}$ and ${ }^{13} \mathrm{C}$ NMR, including uni- and bidimensional techniques; in addition, comparisons were made with data from academic literature. These compounds were identified as: cardanols $(1 a+1 b)$, cardols $(2 a+2 b)$, monoene anacardic acid (3), $\alpha$ amirine (4), $\beta$-amirine (5), cycloartenol (6), 24-methylene-cycloartenol (7) and lupeol (8). The determination of the position of the double bond after a reaction with Dimethyl disulfide (DMDS) is described for the phenol derivatives. The ethanolic extract was tested in vitro for antimicrobial activity by using the disc diffusion method and it showed significant results against Escherichia coli, Staphylococcus aureus, Pseudomonas aeruginosa and Shigella spp.
\end{abstract}

Keywords: Anacardic acid; Antibacterial activity; Triterpenoids; Brazilian propolis; Alkylthiolation.

\section{Introduction}

Propolis is a natural resinous product collected by bees from the buds and exudates of plants. It is used to seal the hives and, more importantly, to prevent the decomposition of creatures that have been killed by bees after invading the hive [1-2]. The use of propolis for various purposes has a long history dating back to at least $300 \mathrm{BC}$ [1] and even now, in the 21st century, it is used in home remedies and personal products [3]. Propolis has also gained popularity in various parts of the world, including the United States, Japan, and the European Union, where it is claimed that it improves human health and prevents conditions such as inflammation, heart disease, diabetes and even cancer. Propolis and its constituents [4-6] are reported to have biological effects, such as being antibacterial, antifungal, cytotoxic, anti-protozoan, antioxidant, anti-inflammatory, antiseptic, spasmolytic and having anesthetic properties.

Although research has concentrated on the Apis mellifera $\mathrm{L}$. bee - because of its commercial appeal - about 20,000 bee species are known worldwide, 1,000 of which collect propolis. Brazil has an estimated 350-600 species, where flora is abundant. Propolis has a very complex chemical composition that varies according to which vegetable source the bees use [7]. The composition of South American propolis varies considerably, as has been shown with Brazilian samples [4.8]. Recently, there has been increasing interest in 
Brazilian propolis [8-9] and many new compounds have been identified [10]. Because most of these studies used propolis from Brazil's south and southeast, we decided to carry out a study on northeastern propolis from the state of Piauí.

This paper describes the isolation and identification of the triterpenoids $\alpha$-amyrin, $\beta$-amyrin, lupeol, cycloartenol and 24-methylenecycloartanol and the phenolic derivatives cardanol, cardol and anacardic acid from propolis produced by Apis mellifera. These compounds are characteristic of Anacardium occidentale L., a family of trees that produces cashew nuts and is commonly called "cajueiro". This paper also describes in vitro evaluation of the antibacterial activity of the ethanolic propolis extract against Escherichia coli, Staphylococcus aureus, Pseudomonas aeruginosa and Shigella spp.

\section{Experimental}

\section{Propolis origins}

The sample of propolis, produced by bees of the species Apis mellifera, was collected in the apiary of the Center for Agrarian Sciences of the Federal University of Piauí, in the city of Teresina - PI (Northeastern Brazil).

\section{Chemical analyses}

Chromatography was carried out on Vetec silica gel 60 (0.063-0.200 mm); Merck silica gel $60(0.2-0.5 \mathrm{~mm})$ and Sigma Sephadex LH-20 columns. Hexane, ethyl acetate, methanol, dichloromethane and acetone were obtained from Merck (analytical grade), Vetec (analytical grade) and Synth (analytical grade).

The ${ }^{1} \mathrm{H}$ and ${ }^{13} \mathrm{C}$ NMR spectra were recorded on a Bruker Avance DRX 500 spectrometer in $\mathrm{CDCl}_{3}$ using TMS as the internal standard $(\delta=0)$.

\section{Chromatographic analysis}

Analysis of the fractions was performed on Shimadzu GC-17A / MS QP5050A (GC/MS system): DB-5HT capillary column (30 m x 0.251 mm, $0.1 \mu \mathrm{m}$ film thickness); carrier gas: helium 1.7 $\mathrm{mL} / \mathrm{min}$; column inlet pressure $107.8 \mathrm{kPa}$; column flow $=1.7 \mathrm{~mL} / \mathrm{min}$; linear velocity $=47.3 \mathrm{~cm} / \mathrm{sec}$; total flow $24 \mathrm{~mL} / \mathrm{min}$; carrier flow $24 \mathrm{~mL} / \mathrm{min}$; injector temperature $300{ }^{\circ} \mathrm{C}$; detector temperature $310{ }^{\circ} \mathrm{C}$; column temperature $100(1 \mathrm{~min})-310^{\circ} \mathrm{C}$ at $10{ }^{\circ} \mathrm{C} / \mathrm{min}(15 \mathrm{~min})$. Mass spectrometer operating conditions $70 \mathrm{eV}$ of ionization energy.

\section{Extraction and isolation of the compounds}

Constituents from a $5.0 \mathrm{~g}$ sample collected in January were isolated by extraction using $50 \mathrm{~mL}$ of methanol in a Soxhlet apparatus for two hours. The extract was filtered while hot, diluted with $25 \mathrm{~mL}$ of water and extracted successively with petroleum ether $(3 \times 75 \mathrm{~mL})$ and diethyl ether $(3 \times 75 \mathrm{~mL})$. The diethyl ether extract (3.29 g) was concentrated and subsequently chromatographed on a silica gel column with mixtures of hexane and diethyl ether of increasing degrees of polarity. Sixty fractions (100 $\mathrm{mL}$ each) were collected. The fractions F-4, F-5 and F-13 eluted with hexane-diethyl ether (3:1) and F51 with hexane-diethyl ether (1:1) were analyzed by ${ }^{1} \mathrm{H}$ and ${ }^{13} \mathrm{C}$ nuclear magnetic resonance (NMR) spectroscopy. Another propolis sample was collected in the same apiary in June and used in an ethanolic extraction carried out by maceration, at room temperature. It was then divided into two parts: one was analyzed to confirm the presence of anacardic acid derivatives and the other part was submitted to antibacterial activity tests.

\section{Methylation}

The fraction containing anacardic acid was subjected to methylation with diazomethane [11]. Methyl esters were prepared by treatment with an excess of previously prepared ethereal diazomethane and maintained at $-20{ }^{\circ} \mathrm{C}$. The reaction, after 3 hours, yielded methyl esters quantitatively, and took place at $5{ }^{\circ} \mathrm{C}$. The solvent was then evaporated in a vacuum. A small portion of the crude reaction was analyzed in GC-MS.

\section{Alkylthiolation reaction}

The position of the double bonds of unsaturated hydrocarbons was determined by iodinecatalyzed methylthiolation using dimethyl disulphide - DMDS [12-14, 22-23]. Approximately 50 $\mathrm{mg}$ of the phenolic fraction was kept dehydrated using anhydrous calcium chloride for 24 hours and then incubated with $0.3 \mathrm{~mL}$ of DMDS containing $10 \mathrm{mg} / \mathrm{mL}$ in ethyl ether of $\mathrm{I}_{2}$ at $25^{\circ} \mathrm{C}$, for 4 hours. After reduction of the excess $\mathrm{I}_{2}$ with a saturated $\mathrm{NaHSO}_{3}$ aqueous solution, $3 \mathrm{~mL}$ of hexane was added into the mixture. $1 \mu \mathrm{L}$ of the hexanic phase was injected into the GC-MS.

\section{Antibacterial activity}

The ethanolic extract of the propolis studied was tested against the following micro-organ- 

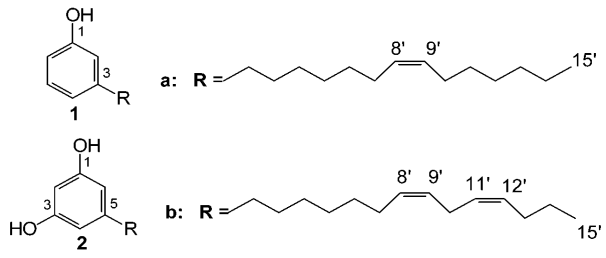

$\mathrm{OH}$
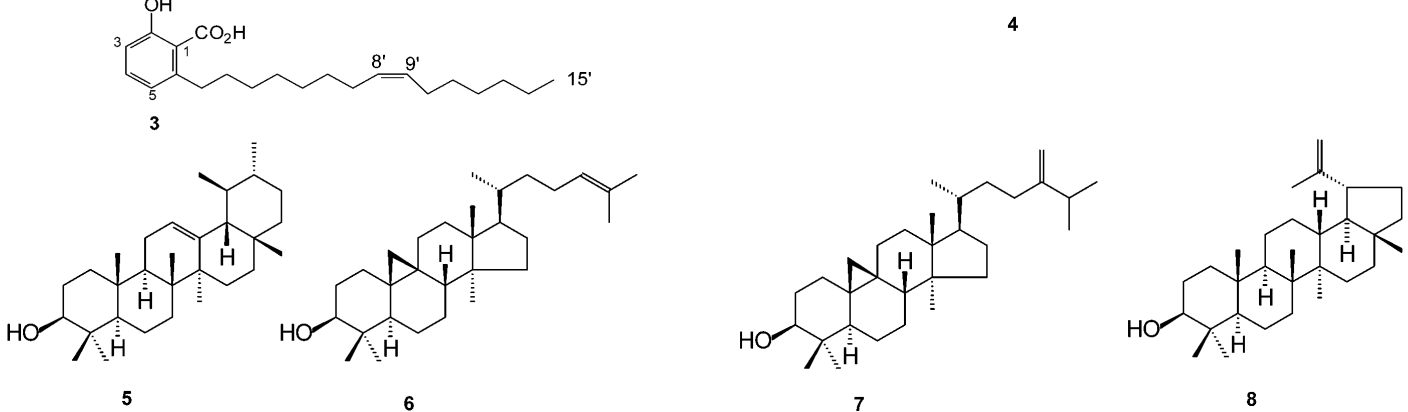

Figure 1. Compounds isolated and/or identified in the methanolic extract of Brazilian propolis (Apis mellifera).

isms: Escherichia coli (ATCC 25922), Pseudomonas aeruginosa (ATCC 26753), Staphylococcus aureus (ATCC 25923) and Shigella sp. The microbiological experiments were carried out using the disc diffusion technique [15]. The inoculations were standardized to $10^{6}$ cfu (colony former unit), using the MacFarland scale. In a Petri dish, a volume of $1 \mathrm{~mL}$ of each suspension was added to $20 \mathrm{~mL}$ of the medium BHI (Brain Heart Infusion), which had been previously melted and subsequently cooled, and homogenized until it solidified. After the medium solidified, filter paper discs (cecon) impregnated with $0.01 \mathrm{~mL}$ of the sample was placed on top of the medium. The plates containing the culture medium were incubated for 24 hours. The results measured the inhibition halos using calipers or an ordinary ruler.

\section{Results and discussion}

The structures were elucidated by ${ }^{1} \mathrm{H}$ and ${ }^{13} \mathrm{C}$ NMR, including uni- and bidimensional techniques, and also compared with data from scientific literature. It was concluded that fraction F5 is a mixture of triterpenoids: $\alpha$-amyrin (4); $\beta$-amyrin (5); cycloartenol (6); 24-methylenecycloartanol (7) and lupeol (8) [9.16-19]. The fractions F4, F-13 and F-51 are composed of a mixture of cardanols $(1 a+1 b)$, cardols $(2 a+2 b)$ and anacardic acid (3), respectively (Figure 1).
The ${ }^{1} \mathrm{H}$ NMR spectrum of fraction F-5 showed signals of between $\delta 5.15$ and 5.06 of olefinic hydrogens, two signals of $\delta 3.20$ and 3.18 of hydroxymethine groups, singlets of methyl hydrogens and allylic methyl group $(\delta 0.6-2.0)$ of triterpenoids and characteristic signals of cyclopropane methylene hydrogens $(\delta 0.28$ and $0.52, \mathrm{~d}, J$ $=4.1 \mathrm{~Hz})$. The structures were also suggested based on some C-13 data, such as 17.5 (C-29), 21.4 (C30), 124.4 (C-12) and 139.6 (C-13) to $\alpha$-amyrin (4); 121.7 (C-12) and 145.2 (C-13), 33.3 (C-29), 23.7 (C-30) to $\beta$-amyrin (5); 20.4 (C-9), 26.0 (C-10), 125.3 (C-24), 130.9 (C-25) to cycloartenol (6); 20.4 (C-9), 26.0 (C-10), 156.9 (C-24) and 105.9 (C-31) to 24-methylenecycloartanol (7); 16.1 (C-25), 150.9 (C-20), 109.3 (C-29) and 19.7 (C-30) to lupeol (8). The NMR ${ }^{1} \mathrm{H}$ and ${ }^{13} \mathrm{C}$ data coincides with that found in other studies [16, 18].

The ${ }^{1} \mathrm{H}$ NMR spectrum of F-4 fraction presented four signals in the aromatic region with the pattern of a 1.3-disubstituted ring, $\delta 6.75(\mathrm{~d}$, H-4) 6.64 (d, H-6), $\delta 6.68(\mathrm{~s}, \mathrm{H}-2)$ and $\delta 7.12(\mathrm{t}$, H-5). Signals at $\delta 5.53-5.42, \delta 2.54-2.59$ and $\delta$ 2.79 were assigned to olefinic, benzylic and double allylic hydrogens, respectively.

The ${ }^{1} \mathrm{H}$ NMR spectrum of F-13 showed two singlets ( $\delta 6.22$ and 5.15) with a relative integration of 2:1, respectively. These NMR signals are characteristic of hydrogen nuclei in a 1,3, 5-trisubstituted aromatic ring with two of them being equivalent. Signals due to olefinic $(\delta 5.33)$, double allylic ( $\delta 2.77-2.74)$, benzylic ( $\delta 2.54$ ) and allylic 
hydrogens ( $\delta$ 2.04-1.98) were also observed. Comparison with data found in other studies [20], showed that fractions F-4 and F-13 are composed of mixtures of cardanols and cardols, respectively. From the relative integration between aromatic hydrogen $(\mathrm{H}-2)$ and allylic hydrogen, it was concluded that the mixtures only contained the monoene and the diene. Because of the double allylic hydrogen signal integration, it was concluded that the mixture is composed of $27 \%$ of diene and $73 \%$ of monoene for the cardols and $60 \%$ of monoene and $40 \%$ of diene for cardanols. This analysis was confirmed by ${ }^{13} \mathrm{C}$ NMR spectroscopy (Table 1) which showed a good correlation between observed and calculated ${ }^{13} \mathrm{C}$ chemical shifts, using the principle of substituent additivity [21].

The ${ }^{1} \mathrm{H}$ NMR spectrum of the F-51 fraction showed it is composed of the anacardic acid monoene. The spectrum consists of three signals for a 1,2,3-trisubstituted aromatic ring at $\delta 7.30$ $(\mathrm{t}, \mathrm{J}=7.9 \mathrm{~Hz}, \mathrm{H}-4) \delta 6.83(\mathrm{~d}, \mathrm{~J}=8.3, \mathrm{H}-5)$ and $\delta$ $6.72(\mathrm{~d}, \mathrm{~J}=7.4, \mathrm{H}-3)$. All the other signals are compatible with the structure (3).

According to academic literature, the methylenic benzylic hydrogens of anacardic acid, due to the presence of the ortho carboxylic group, appear more deshielded $(\delta 2.94)$ than those in cardol $(\delta 2.56)$ and cardanol $(\delta 2.54)$ [24]. The ${ }^{13} \mathrm{C}$ NMR and GC-MS data confirm this analysis.

The cardanolic fractions (F4) were submitted to alkylthiolation reaction, while the methylated acid anacardic fraction (F-51) was submitted to methylation with diazomethane followed by alkylthiolation reaction, according to experimental. Both the phenolic hydroxyl and carboxylic group were methylated. Mass Spectra (Figure 2) were present as main fragments: m/z $374\left(\mathrm{M}^{+}\right), \mathrm{m} / \mathrm{z} 314$ (McLafferty), m/z $343\left(\mathrm{M}^{+}-\mathrm{CH}_{3} \mathrm{O}\right)$ and m/z 180 (benzylic rearrangement, cleavage at 1.2).
Table 1. ${ }^{13} \mathrm{C}$ NMR data for cardanols $(1 \mathrm{a}+1 \mathrm{~b})$, cardols $(2 \mathrm{a}+2 \mathrm{~b})$ and anacardic acid (3) (125 MHz, $\mathrm{CDCl} 3)$.

\begin{tabular}{lccc}
\hline $\mathrm{C}$ & $1 \mathrm{a}+1 \mathrm{~b}^{*}$ & $2 \mathrm{a}+2 \mathrm{~b}^{* *}$ & $3^{* * *}$ \\
\hline 1 & 155.5 & 156.6 & 111.1 \\
2 & 115.4 & 100.2 & 163.4 \\
3 & 145.0 & 156.6 & 115.7 \\
4 & 121.0 & 108.1 & 134.9 \\
5 & 129.4 & 146.2 & 122.6 \\
6 & 112.5 & 108.1 & 147.6 \\
1, & -------- & 35.9 & 36.5 \\
8, & 129.9 & 129.9 & 129.9 \\
9 & 130.1 & 129.9 & 129.9 \\
13 & 31,7 & 31,7 & 31,7 \\
14 & 22,5 & 22,5 & 22,5 \\
15 & 14.0 & 14.1 & 14.1 \\
$\mathrm{C}=\mathrm{O}$ & --------- & ------- & 175.2 \\
\hline
\end{tabular}

* $\delta 130.1$ (C8'); 130.2 (C9'); 128.2 (C-11'), 128,4 (C12'); 35.8 (C-13'); 23,1 (C-14) in 1b;

** $\delta 130.3$ (C8'); 130.2 (C9'); 128.1 (C-11'); 128.0 (C12' in 2b)

*** $\delta$ 30,9 (C2'); 29.0 (C3’); 29.5 (C-4'); 29.5 (C5'), 29.5 (C5'), 29.7 (C6'), 33.4 (C7') in 3.

The determination of the positions of double bonds after the addition of dimethyl disulfide (DMDS) is described for cardanol (1a) and anacardic acid (3a) as ester. The mass spectra (electron impact $70 \mathrm{eV}$ ) show molecular ions $\left(\mathrm{M}^{+}\right)$and give key fragments that permit one to determine the position of the original double bond. Cleavage between the sulfur-substituted carbons leads to key fragments which allow one to determine the position of the double bond in the original mono-unsaturated phenolic compound. The spectrometer was set to scan ions of $\mathrm{m} / \mathrm{z} 396,381,154$ and 107 to cardanol fraction (with the double bond at C-8), while for methylated anacardic acid fraction we detected ions m/z $468\left(\mathrm{M}^{+}\right), 453\left(\mathrm{M}^{+}\right.$- 15) 323

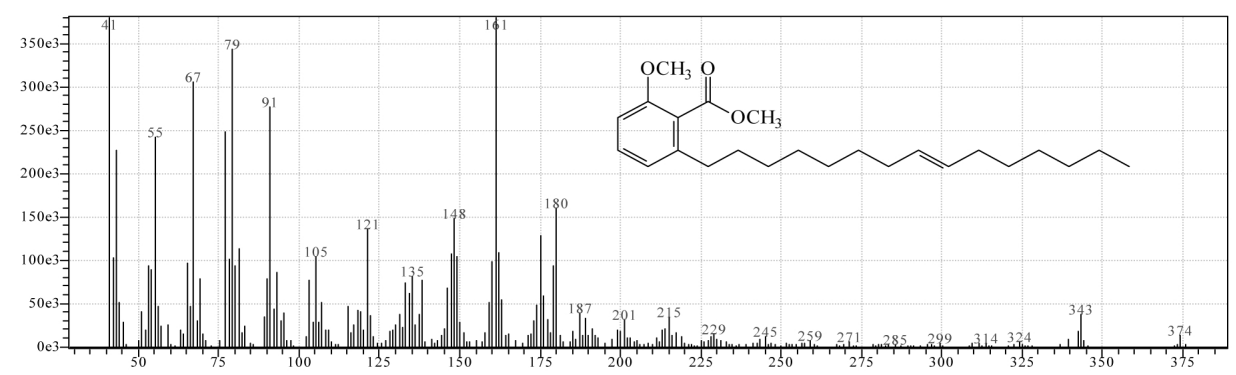

Figure 2. Mass spectrum of the methyl ester of the anacardic acid, GC/EI-MS (70 eV). 


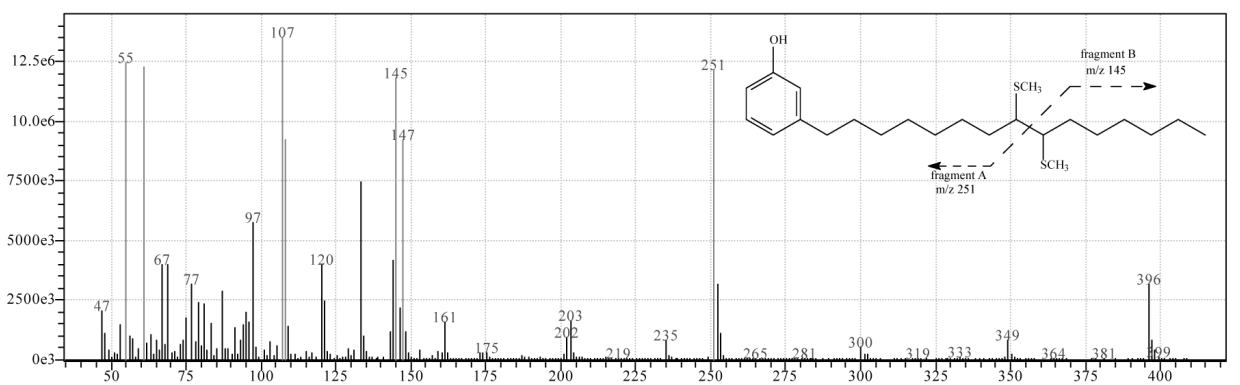

Figure 3. Mass spectrum of the cardanol (1a), GC/EI-MS (70 eV), after lkylthiolation Reaction of the fraction F-4.

(fragment A), 145 (fragment B) as the main fragments. We presented typical mass spectra to cardanolic fraction (1a). This fraction gave a low relative abundance of cardol ( $2 \mathrm{~b}$ ), and it was not possible to determine the position of the double bonds in this experiment. According to other reports [14,2223], if the double bonds are interrupted with more than four carbon atoms, an independent derivation of the alkenes occurs. When the double bonds are closer together, (such as in cardol, and alkene units interrupted by one methylene group) a complex product mixture is formed. Derivation reactions at higher temperatures $\left(60{ }^{\circ} \mathrm{C}\right)$ and longer reaction periods $(40 \mathrm{~h})$ result in cyclizations and give complicated heterocyclic compounds.

The presence of anacardic acid derivatives in propolis has not been previously reported and may have occurred because of the presence of several cashew trees (Anacardium occidentale) in the apiary neighborhood. These results were confirmed by analysis of propolis samples collected in the same apiary, but in another season, which also contained these compounds. The plant source is of crucial importance for the chemical composition and thus, for the biological activity of propolis from a particular region [25].

The biological activities of the anacardic acid derivatives have attracted considerable attention for acting as molluscicides [26], anti-tumour agents [27-28], antimicrobes [29-32], antioxidants [33] and xanthine oxidase inhibitiors [34].

It was shown that the ethanolic extract has an antibacterial effect against Escherichia coli (zone of inhibition $=11 \mathrm{~mm}$ ); Pseudomonas aeruginosa (zone of inhibition $12 \mathrm{~mm}$, Staphylococcus aureus (zone of inhibition $=11 \mathrm{~mm}$ ) and Shigella spp (zone of inhibition $=10 \mathrm{~mm}$ ). Standard DMSO (dimethylsulfoxide) was used as a negative control.
This class of compounds, present in Anacardium occidentale, is also present in Ginkgo extracts; in the former they are called anacardic acids and in the latter ginkgolic acids, but both classes are 6-alkylsalicylic acids or 2-hydroxy-6alkylbenzoic acids. Although the Anacardium extracts are reported to be antitumour agents $[27,28,30,31]$ and non-carcinogenic, the Ginkgo extracts are reported to be cytotoxic agents $[35,36,37]$. However, it should be noted that there is no solid proof of a strong allergic reaction to these alkyl-phenols when taken orally [38].

\section{Conclusion}

The propolis samples obtained in different seasons from an Apis mellifera apiary at the Federal University of Piauí showed the unusual presence, among other terpenic compounds, of anacardic acid derivatives. The position of the double bonds of the cardanol and anacardic acid, in C-8, was confirmed by iodine-catalysed methylthiolation using dimethyl disulphide. The ethanolic extract had an antibacterial effect against Escherichia coli, Pseudomonas aeruginosa, Staphylococcus aureus and Shigella spp.

\section{Acknowledgements}

The authors acknowledge the financial support of CAPES (Coordenação de Aperfeiçoamento de Pessoal de Nível Superior) and CENAUREMN - UFC, for providing the NMR spectra.

Received 15 February 2008 Accepted 19 June 2008 
M. S. S. Silva, S. G. De Lima, E. H. Oliveira, J. A. D. Lopes, M. H. Chaves, F. A. M. Reis, A. M. G. L. Citó. Derivados de Ácido Anacárdico de Própolis Brasileira e sua Atividade Antibacteriana.

Resumo: A própolis é um produto resinoso que as abelhas recolhem de certas partes da planta e que apresenta excelentes propriedades medicinais. Este trabalho descreve a isolamento e identificação de triterpenóides e derivados de ácido anacárdico de própolies Brasileira e sua anti-atividade. Suas estruturas foram elucidadas por $\mathrm{RMN}{ }^{1} \mathrm{H}$ e ${ }^{13} \mathrm{C}$, incluindo técnicas uni e bidimensionais, e comparação com dados da literatura. Os compostos foram caracterizados como: cardanóis $(1 \mathrm{a}+1 \mathrm{~b})$, cardóis $(2 \mathrm{a}+2 \mathrm{~b})$, ácido anacárdico monoeno (3), a-amirina (4), b-amirina (5), cicloartenol (6), 24-metileno-cicloartenol (7) e lupeol (8). A determinação da posição da ligação dupla após reação com dissulfeto de dimetila (DMDS) é descrita para os derivados fenólicos. O extrato etanólico foi testado in vitro para atividade anti-bacterina pelo método de difusão em disco e mostrou resultados significativos contra Escherichia coli, Staphylococcus aureus, Pseudomonas aeruginosa e Shigella spp.

Palavras-Chave: Ácido anacárdico; Atividade anti-bacteriana; Triterpenóides, Própolis brasileira, alquiltiolação.

\section{References}

[1] E. L. Ghisalbert, Bee World. 60 (1979) 59

[2] C. Garcia-Viguera, W. Greenaway, F. R. Watley, Z. Naturforsch., Tubigen. 47c (1992) 634.

[3] T. Usia, A. H. Banskota, Y. Tezuka, K. Midorikawa, K. Matsushige, S. Kadota, J. Nat. Prod. 65 (2002) 673.

[4] M. C. Marcucci, Apidologie. 26 (1995) 83.

[5] G. A. Burdock, Food Chem. Toxicol. 36 (1998) 347.

[6] A. H. Banskota, T. Nagaoka, L. Y. Sumioka, Y. Tezuka, S.

Awale, K. Midorikawa, K. Matsushige, S. J. Kadota,

Ethnopharmacology. 80 (2002) 67.

[7] V. S. Bankova, A Diulgerov., S. S. S. Popov, , L. Evstatieva,

L. Kuleva, O. Pureb, Z Zamjasan, Apidologie, 23 (1992) 79.

[8] V. Bankova, S. L. Castro, M. C. Marcucci, Apidologie, 31

(2000) 3.

[9] A. S. Pereira, E. A. Nascimento, F. R. Aquino Neto, Z. Naturforsch., 57c (2002) 721.

[10] M. S. S. Silva, A. M. G. L. Citó, M. H. Chaves, J. A. D. Lopes, Quím. Nova, 28 (2005) 801.

[11] S. G. De Lima "Síntese e Identificação de Biomarcadores em Óleos da Bacia de Campos e Bacia Potiguar: Identificação de 3-alquil-esteranos". Tese de Doutorado. Unicamp Instituto de Química, Campinas-SP - Brasil, 2005, 350p.

[12] C. Wang. The role of lipids in disease resistance and fruit ripening tomato. Ph.D. Thesis. Rutgers University, New Brunswick, N.J., 1998.

[13] G. W. FRANCIS, K. VELAND, J. Chromatogr., 219 (1981) 379-384.

[14] Lizhi Zhu. Investigating The Biosynthesis Of Polyacetylenes: Synthesis of Deuterated Linoleic Acids \& Mechanism Studies of DMDS Addition to 1,4-Enynes. Ph.D. Thesis. Miami University-The Graduate School, Usa. Oxford, Ohio, 2003, 104p.

[15] P. R. Murray, W. L. Drew, G. S. Kobayasai, J. R. Thompson, "Microbiologia Médica,". Guanabara Koogan, Rio de Janeiro, 1990.

[16] N. F. Roque, R. S. G. Olea, Quim. Nova, 13 (1990) 278

[17] S. B. Mahato, A. P. Kundu, Phytochemistry, 37(1994) 1517.

[18] F. W. Wehrli, T. Nishida, "The Use of Carbon-13 Nuclear Magnetic Resonance Spectroscopy in Natural Product
Chemistry," in Zechmeister, L. et al. Progress in the Chemistry of Organic Natural Products. Wi Springer-Verlag, New York, 1979. p.93.

[19] L. Radics, M. C. Kajtarperedy, S. Corsano, L. Standoli, Tetrahedron. Lett., 48 (1975) 4287.

[20] P. H. Gedam, P. S. Sampathkumaran, M. A. Sivasamban, Indian J. Chem., 10 (1972) 388

[21] E. Pretsch, T. Clerc, J. Seibl, W. Simon, "Tables of spectral data for structure determination of organic compounds," $2^{\text {nd }}$ ed, Springer-Verlag, New York, 1989.

[22] N. M. Carballeira, F. Shalabi, C. Cruz, Tetrahedron Lett. $1994,35,5575$.

[23] W. W. Christie, Lipid Technol., 9, (1997) 17.

[24] J. H. P. Tyman, N. Jacobs, J. Chromatogr., 54 (1971) 83.

[25] R. Christov, B. Trusheva, M. Papova, V. Bankova, M. Bertrand, Nat. Prod. Res., 19 (2005) 673.

[26] I. Kubo, S. Komatsu, M. J. Ochi, Agric. Food Chem., 34 (1986) 970.

[27] H. Itokawa, N. Totsuka, K. Nakahara, K. Takeya, J. P. Lepoittevin, Y. Asakawa, Chem. Pharm. Bull., 35 (1987) 3016. [28] H. Itokawa, N. Totsuka, K. Nakahara, M. Maezuru, K. Takeya, M. Kondo, M. Inamatsu, H. Morita, Chem. Pharm. Bull., 37 (1989) 1619

[29] M. Himejima, I. Kubo, J. Agric. Food Chem., 39 (1991) 418. [30] I. Kubo, H. Muroi, M. Himejima, Y. Yamagiwa, H. Mera, K. Tokushima, S. Ohta, T. Kamikawa, J. Agric. Food Chem., 41 (1993) 1016

[31] I. Kubo, M. Ochi, P. C. Vieira, S. Komatsu, J. Agric. Food Chem., 41 (1993) 1012

[32] H. Muroi, I. Kubo, J. Agric. Food Chem., 41 (1993) 1780.

[33] R. Amorati, G. F. Pe dulli, L. Valgimgli, , O. A. Attanasi, P. Filippone, C. Fiorucci, R. Saladino, J. Chem. Soc., Perkin Trans., 2 (2001)2142.

[34] N. Masuoka, I. Kubo, Biochimi. Biophysi. Acta, 1688 (2004) 245.

[35] C. P. Siegers, Phytomedicine, 6 (1999) 281.

[36] J. Westendorf, J. Regan, Pharmazie, 55 (2000) 864.

[37] H. Hecker, R. Johannisson, E. Koch, C. P. Siegers, Toxicology, 177 (2002) 167.

[38] M. T. S. Trevisan, B. Pfundstein, R. Haubner, G. Wurtele, B. Spiegelhalder, H. Bartsch, R.W. Owen, Food Chem. Toxicol., 44 (2006) 188. 